\title{
Mechanistic Study of Antibacterial Properties of Chemically Synthesize Zinc Oxide (ZnO) Nanoparticles
}

\author{
Abdur Rehman ${ }^{1}$, Saira Ahmad ${ }^{2}$, Abdul Mateen ${ }^{3}$, Huma Qamar ${ }^{4}$, \\ Mudaber Ahmad Mubashar ${ }^{5}$, Ali Raza ${ }^{1}$, Waqas Ali ${ }^{1}$, Adnan Arshad ${ }^{6 *}$ \\ ${ }^{1}$ Department of Physics, University of Agriculture Faisalabad 38000, Punjab, Pakistan \\ ${ }^{2}$ School of Biological Sciences, University of the Punjab Lahore 54590, Punjab, Pakistan \\ ${ }^{3}$ Department of Plant Pathology, College of Plant Protection, China Agricultural University \\ Beijing 100193, China \\ ${ }^{4}$ Oilseeds Research Institute, Ayub Agricultural Research Institute, Faisalabad 38000, Pakistan \\ ${ }^{5}$ Department of Physics University of Siegen 57080, Germany \\ ${ }^{6}$ College of Resources \& Environmental Sciences, China Agricultural University Beijing 100193, China \\ * Corresponding author email: ad@ cau.edu.cn
}

Received: 24 July 2019 / Revised: 11 October 2019 / Accepted: 20 October 2019 / Published: 21 October 2019

\begin{abstract}
Nanotechnology is the science, engineering and technology conducted at the scale that ranges between 1-100 nanometers. For the bio-application, evolution of nanotechnology is creating the concern of scientists towards the synthesis of nanoparticles. The nanoparticles have unique characteristics as compare to bulk materials. Zinc oxide $(\mathrm{ZnO})$ is a matchless semiconductor and it has been under investigation due to its wide range of applications in various areas like biomedical, electronics, material science and optics. In the present work synthesis of $\mathrm{ZnO}$ nanoparticles was carried out by using simple chemical approach, Sol-gel method for being effective and inexpensive, by employing zinc acetate dehydrate $\mathrm{Zn}\left(\mathrm{CH}_{3} \mathrm{CO}_{2}\right)_{2} \cdot 2 \mathrm{H}_{2} \mathrm{O}$ as a precursor and sodium hydroxide $(\mathrm{NaOH})$ starch as a constant agent. The structural properties of resultant zinc oxide nanoparticles were investigated by X-ray diffraction (XRD) technique. The XRD data confirmed the hexagonal wurtzite structure of $\mathrm{ZnO}$ powder confirmed by JCPDS 36-1451 data. Particles size was calculated by Scherrer formula and calculated size was $30.14 \mathrm{~nm}$. These nanoparticles were investigated for inhibition zone of bacterial strain Escherichia coli, a gram-negative microbe, at various concentrations of $\mathrm{ZnO}$ nanoparticles. Zinc oxide nanoparticles were very proficient for inhibition of growth of bacterial strain E. coli. The mechanism of $\mathrm{ZnO}$ NPs for antibacterial activity is release of reactive oxygen species which not only hydrolyze cell wall but cell membrane and cellular components as well providing a potential bactericidal effect.
\end{abstract}

Keywords: Nanotechnology, $\mathrm{ZnO}$ nanoparticles, Antibacterial synthesis.

\section{Introduction}

Technologies have lead mankind to bring possibilities with comfort in every aspect of life. Dawn of nanotechnology has enabled synthesis of nano-scale particles with size of below $100 \mathrm{~nm}$ in one or more dimensions, termed as nanoparticles [1]. Nanoparticles with small size and large surface area offer scientific research owing to new horizon of applications in fields like biosensor, optical, agriculture, cosmetics, food industry, electronics, medical, diagnostics and nano-biotechnology [2-4]. Nanoparticles especially inorganic metal oxides like $\mathrm{ZnO}, \mathrm{MgO}, \mathrm{CaO}, \mathrm{CeO}, \mathrm{CuO}, \mathrm{AL}_{2} \mathrm{O}_{3}, \mathrm{Ag}_{2} \mathrm{O}$ and $\mathrm{TiO}$ have potential for antimicrobial activity seems to be promising candidate for their use against various microbes [2, 5-9]. Adducts of halogens like chloride and bromide with $\mathrm{MgO}$ nanoparticles have potent antimicrobial activity for bacteria as well as spores [2].

Zinc oxide with chemical formula $\mathrm{ZnO}$ and its molar mass is $81.38 \mathrm{~g} / \mathrm{mol}$. , is an inorganic composite white powder that is insoluble in water and it is widely used as an additive in numerous materials and products 
including rubbers and plastic manufacturing. Other names of zinc oxide are calamine, Chinese white, zinc white and flower of zinc. This inorganic composite also known as zincite and arise rarely in nature, normally in a crystalline appearance. It is generally red or orange in color due to existence of manganese impurity. It frequently appears as a white crystalline residue. Crystalline $\mathrm{ZnO}$ is thermochromic, which modify from white to yellow color when intense and reverting to white color on cooling. This change in color is reason by a very little loss of oxygen at high temperatures. $\mathrm{ZnO}$ decomposes to form zinc vapor and oxygen at around $1975^{\circ} \mathrm{C}$ indicating its considerable constancy. Heating with carbon changes $\mathrm{ZnO}$ into $\mathrm{Zn}$, which is more unpredictable. Commercial zinc oxide demonstrates a computable but low stage of water solubility, $0.005 \mathrm{~g} /$ liter. Many $\mathrm{ZnO}$ nanomaterial which is used commercially and formed synthetically. $\mathrm{ZnO}$ is essentially a large band gap semiconductor of the II-VI semiconductor group. The doping of the semiconductor is n-type which is due to oxygen vacancies. That has numerous positive properties like good transparency, high electron mobility, wide bandgap for semi-conductivity, high room temperature luminescence etc.[10][11].

Nanostructures of zinc oxide can be prepared into a variety of morphologies including nanorods, nanowires, nanoflower, tetrapods, nanobelts, nanoparticles etc. Zinc oxide nanoparticles Zn stand out as one of the most versatile materials, due to their functionalities, diverse properties and applications. Zinc oxide nanoparticles have tremendous optical properties, it possesses antimicrobial actions against some fungi and bacteria. The colloidal solution of $\mathrm{ZnO}$ nanoparticles is used in nano-fertilizers also it increases the growth and yield of the crops. As the demand of food is increasing day by day the yield of staple food crops is much low. So it is the time to commercialize metal nanoparticles for supportable agriculture [12]. Since microbes have severe health affects not only in mankind but other living organisms. Antibiotic resistance developed by the pathogenic bacteria has made difficult to cop up with infectious diseases posing serious threat to health [13]. ZnO nanoparticles are being extensively studied and used for their antimicrobial activities against Gram positive and negative bacteria under visible light[14]. The mechanism of action of $\mathrm{ZnO}$ nanoparticles is suggested to be disruption of microbial cell membrane and cell wall by employing reactive oxygen species (ROS) like $\mathrm{OH}-\mathrm{H}_{2} \mathrm{O}_{2}$, and $\mathrm{O}_{2}{ }^{2-}$. $\mathrm{ZnO}$ nanoparticles are Generally Recognized As Safe (GRAS) by US Food and Drug Authority (FDA) [15].

$\mathrm{ZnO}$ nanoparticles are being used as food additives, anticancer, anti-inflammatory and drug delivery [1618]. The concentration of $\mathrm{ZnO}$ nanoparticles is critical for drug delivery, anti-cancer and anti-inflammatory administered to affected individuals [19]. The anti-cancer activity involves the similar mechanism as in antimicrobial activity, production of ROS and leading to programmed cell death known as apoptosis [20]. In case of anti-microbial activity, which is size dependent of $\mathrm{ZnO}$ NPs as well as specie of bacteria [21]. Bacteria are tiny living beings (microorganisms). Most of Bacteria are classified in two categories based upon differential staining procedure on the basis of cell wall composition, Gram positive and negative bacteria. Gram-positive bacteria have a thick mesh-like cell wall which is made up of peptidoglycan (50$90 \%$ of cell wall), which stains purple. Peptidoglycan is mainly a polysaccharide composed of two subunits called $\mathrm{N}$-acetyl glucosamine (NAG) and $\mathrm{N}$-acetyl muramic acid (NAM). As adjacent layers of peptidoglycan are formed, they are cross linked by short chains of peptides by means of a trans-peptidase enzyme, resulting in the shape and rigidity of the cell wall [22]. The thick peptidoglycan layer of Gram-positive organisms allows these organisms to retain the crystal violet-iodine complex and stains the cells as purple. Gramnegative bacteria have a thinner layer of peptidoglycan (10\% of the cell wall) and lose the crystal violetiodine complex during decolorization with the alcohol rinse, but retain the counter stain Safranin, thus appearing reddish or pink [23]. They also have an additional outer membrane which contains lipids, which is separated from the cell wall by means of periplasmic space. The cell wall of Gram-negative bacteria is often a virulence factor that enables pathogenic bacteria to cause disease[22].

Nowadays, numerous methods have been employed to control or prevent the growth of pathogens in food by the involvement of synthetic and natural antimicrobial agents. In recent years, nanoparticles play crucial role in food preservation and packaging. In the present investigation, the $\mathrm{ZnO}$ nanoparticles were synthesized using wet chemical approach [24]. The structural characterization of $\mathrm{ZnO}$ nanoparticles were 
carried out using X-ray Diffractometer. Furthermore, the antimicrobial activity of $\mathrm{ZnO}$ nanoparticles were carried out against Escherichia coli. The objective of the present research work was synthesis of zinc oxide $(\mathrm{ZnO})$ nanoparticles by using chemical approach. The obtained nanoparticles were characterized using XRD technique antibacterial properties of synthesized zinc oxide nanoparticles were studied.

\section{Material and methods}

\subsection{Preparation of $\mathrm{ZnO}$ nanoparticles}

A Sol Gel method is used for the synthesis of zinc oxide nanoparticles in the powder form. ZnO NPs were prepared by sol gel method employing zinc acetate dehydrate ( $99.9 \%$ of Sigma now is Merck) dissolved in distilled water [25]. The clear solution with $0.2 \mathrm{M}$ of zinc acetate dehydrate was obtained by magnetic stirrer mixing for $60 \mathrm{~min}$. The prepared solution was mixed with $0.1 \mathrm{M} \mathrm{NaOH}(\geq 97 \%$ ACS grade Merck) which was subjected to filtration with porosity in microns. The glass beaker containing filtrate was placed in oven for 3 hours at $60^{\circ} \mathrm{C}$ for drying purpose. The dried gelatin structure was grinded with mortar and pestle to get fine powder. The structural elucidation was performed by X-Ray diffraction.

\subsection{Antibacterial properties of $\mathrm{ZnO}$ Nanoparticles}

\subsubsection{Optical density}

Antibacterial activity of $\mathrm{ZnO}$ NPs was observed against gram negative bacterial specie E.coli DH5 $\alpha$ by optical density and plate method. For optical density, serial dilutions of various concentrations of $\mathrm{ZnO} N P s$ were prepared in sterilized nutrient growth media, bacterial strain was inoculated and incubated at $37^{\circ} \mathrm{C}$ for 15 to 24 hrs. Optical density was measured at $600 \mathrm{~nm}$ by UV-Vis spectrophotometer (Shimadzu 1700).

\subsubsection{Minimum inhibitory concentration assay}

To determination of minimum inhibitory concentration (MIC) against E.coli $\mathrm{DH} 5 \alpha$, various concentration containing microbial test tube cultures were spread over nutrient agar plate, incubated at $37^{\circ} \mathrm{C}$ for $8 \mathrm{hrs}$. Colonies were counted by colony counter. The concentration at which the number of colonies falls below $30 \mathrm{cfu} / \mathrm{mL}$ was considered as Minimum Bactericidal Concentration (MBC) and the concentration at which the growth of bacteria was completely absent was taken as MIC.

\subsubsection{Zone of Inhibition}

The zone of inhibition was determined by the recommended procedure by CLSI (Clinical and Laboratory Guidelines)[26]. For this instance, $\mathrm{ZnO}$ NPs disc with size of $1.5 \mathrm{~mm}$ diameter containing (an amount of $\mathrm{ZnO} N P s$ ) prepared as shown in table 1. Fresh microbial culture was swabbed on Muller Hinton agar $(\mathrm{MH})$ plates, $\mathrm{ZnO}$ NPs discs were applied in quartile in a plate and incubated at $37^{\circ} \mathrm{C}$ for $24 \mathrm{hrs}$. Each experiment was performed in triplicate. The inhibition zones are given as the means and standard deviation [27].

Table 1: Amount of $\mathrm{ZnO}$ used for antibacterial activity

\begin{tabular}{|c|c|c|c|}
\hline \multicolumn{2}{|c|}{ Set A } & \multicolumn{2}{|c|}{ Set B } \\
\hline Stock concentration & $\begin{array}{c}\text { ZnO NPs amount in } \\
\text { disc }\end{array}$ & Stock concentration & $\begin{array}{c}\text { ZnO NPs amount in } \\
\text { disc }\end{array}$ \\
\hline \multirow{3}{*}{$0.4 \mathrm{mg} / \mu \mathrm{L}$} & $8 \mathrm{mg}$ & \multirow{3}{*}{$0.8 \mathrm{mg} / \mu \mathrm{L}$} & $16 \mathrm{mg}$ \\
\cline { 2 - 2 } & $16 \mathrm{mg}$ & $32 \mathrm{mg}$ \\
\cline { 2 - 2 } & $24 \mathrm{mg}$ & $48 \mathrm{mg}$ \\
\hline
\end{tabular}

The $\mathrm{ZnO}$ nanoparticles have anti-bacterial activity since the commonly occurring bacteria cannot withstand in the oxidative stress produced on the surface of the $\mathrm{ZnO}$ nanoparticles. Ultimately, the use of this nanoparticle leads to the damage of the bacterial cell membrane and causes leakage of the cellular fluid through cell lyses. However, there was variation in the inhibition of bacteria due to the dissimilarity in various factors such as surface morphology crystallite structure, defects, size and shape of the particles. Here, the obtained $\mathrm{ZnO}$ nanoparticles were tested for the anti-bacterial activity against bacterial stain gram 
negative E. coli. To check the bacterial inhibition property of prepared $\mathrm{ZnO}$ nanoparticles, minimum inhibition concentration (MIC), zone of inhibition, cell viability test were evaluated.

\section{Results and Discussion}

The development of nanotechnology is making the interest of researchers towards the synthesis of nanoparticles for the bio-application. Metal oxides such as $\mathrm{ZnO}$ have received increasing attention as antibacterial materials in recent years because of their stability under harsh processing conditions and also because they are generally regarded as safe materials for human beings and animals. Zinc activates 300 enzymes and it plays a role in many another phenomenon like growth, membrane stability, bone mineralization, tissue growth, and repair, wound healing and cell signaling. The wide existence of zinc in nature makes the use of zinc as non-toxic agent. Many studies have shown that $\mathrm{ZnO}$ nanoparticles have enhanced antibacterial activity. Use of plant and plant materials for the synthesis of Zinc nanoparticles is relatively new and exciting research field. Various plants were used for the synthesis of nanoparticles using green synthesis method. Nanoparticles were synthesized from all the parts of the plant separately like stem, flower, leaf, latex, root, peel, stem bark and fruits. The prepared nanoparticles of Zinc oxide were characterized by using XRD, UV-VIS Spectroscopy, FTIR, EDAX, Particle size analyzer, TGA, and SEM. In this research Zinc Oxide nanoparticles (ZnO-NPs) prepared by a Bottom-Up chemical technique (named Sol-Gel method) from a zinc acetate precursor and sodium hydroxide, because this technique has many advantages over other methods (like Spray pyrolysis, Rapid solidification process, Liquid infiltration and Ball milling) which are high cost, high temperature associated and formation of undesired products during Process [28]. The choice employed for the preparation of $\mathrm{ZnO}$ nanoparticles is Sol-Gel method which utilizes alkaline solution leads to hydrolysis of metal precursor forming a gel structure by removal of water. The gelatinized body gives high quality fine powder of $\mathrm{ZnO}$ by elimination of solvent. The fine powder is attributing factor especially size of nanoparticles. The small size of nanoparticles is proportional to the surface area which comes encountering the effectiveness and activity of nanoparticles. The effectiveness of using Sol-Gel method has wide range in the field of material sciences because it ensures better control of structure in terms of particle size, also ensures better homogeneity in the mixing of molecular level. Elemental composition of $\mathrm{ZnO}-\mathrm{NPs}$ determined by a versatile and rapid analytical technique "X-ray diffraction".

\subsection{X -ray Diffraction (XRD) Analysis}

The prepared samples of $\mathrm{ZnO}$ were examined with the help of $\mathrm{X}$-ray diffraction is used for the structural analysis. The Scherrer formula used to calculate the crystallite size of zinc oxide nanoparticles is:

$$
t=\frac{0.9 \lambda}{B \cos \theta_{B}}
$$

Where ' $\mathrm{B}$ ' is full width half maximum taken in radian, ' $\lambda$ ' is the wavelength of the $\mathrm{X}$-rays used and for Copper $\mathrm{K} \alpha$ it is $0.15406 \mathrm{~nm},{ }^{\prime} \theta_{\mathrm{B}}$ ' is the angle between the incident and diffracted beam and ' $\mathrm{t}$ ' is the crystallite size. This technique provides phase identification of a crystalline material and gives detailed information of a "Unit cell dimension". The crystalline structure (lattice positions) has been refined by using the "Scherrer method". X-ray diffraction (XRD) patterns of zinc oxide samples were recorded using X-ray diffractometer using $\mathrm{Cu}-\mathrm{Ka}$ radiation $(\lambda=1.540598 \mathrm{~A})$ with 2 theta ranging from 20 to 80 .The XRD pattern of zinc oxide sample as shown in figure 1, with their corresponding XRD data (d-spacing, 2 theta values, half maximum intensity and relative intensity) are given from table 2 identify the peaks and phase transformation.

The peak observed at $2 \theta=31.96,34.62,36.45,47.80,56.88,63.07$ and 68.17 correspondence to the lattice plane (100), (002), (101), (102), (110), (103) and (112) respectively, symptomatic of wurtzite hexagonal structure of $\mathrm{ZnO}$. The rooming of the peaks gives an idea of the synthesized $\mathrm{ZnO}$ small particle size. The crystalline size of $\mathrm{ZnO}$ sample boarding of the peak (101) was calculated using Scherrer's formula: $\mathrm{D}=$ 0.9/B $\operatorname{Cos} \theta$, where B, $\theta$ are X-ray wavelength, FWHM (full width at half maximum) and Bragg diffraction 


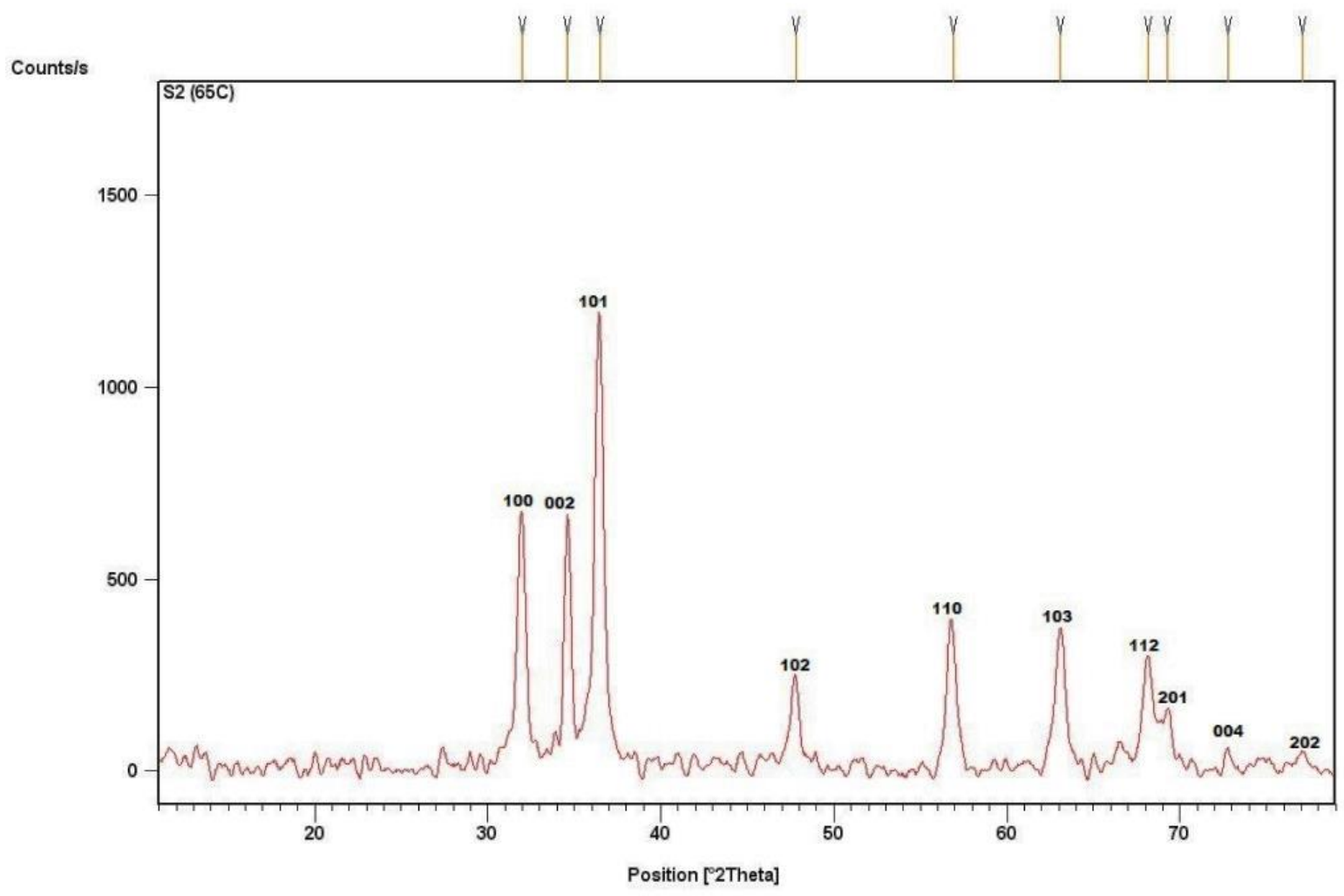

angle separately. Calculated size was $30.14 \mathrm{~nm}$. Lattice constants were also calculated peak positioned at $2 \theta$ $=36.45[29,30]$ and Lattice parameters were measured using respective miller indices[31].

Figure 1: $d$-Spacing $X$-ray diffraction peaks for $\mathrm{ZnO}$ nanoparticles.

Table 2: Peak analysis of Zinc oxide nanoparticles

\begin{tabular}{|c|c|c|c|c|}
\hline No. & Pos. ['2Th.] & d-spacing [̊] & FWHM [ ${ }^{\circ}$ 2Th.] & Rel. Int. [\%] \\
\hline 1 & 31.9643 & 2.79997 & 0.1968 & 56.09 \\
\hline 2 & 34.627 & 2.59051 & 0.0984 & 54.57 \\
\hline 3 & 36.4567 & 2.46459 & 0.3147 & 100 \\
\hline 4 & 47.8021 & 1.90281 & 0.2755 & 19.57 \\
\hline 5 & 56.8862 & 1.61864 & 0.3149 & 32.39 \\
\hline 6 & 63.0779 & 1.47385 & 0.3149 & 31.09 \\
\hline 7 & 68.1725 & 1.37559 & 0.4723 & 23.26 \\
\hline 8 & 69.2567 & 1.35668 & 0.4723 & 11.81 \\
\hline 9 & 72.7513 & 1.29989 & 0.4723 & 4.8 \\
\hline 10 & 77.0905 & 1.23617 & 1.152 & 4.13 \\
\hline
\end{tabular}

In the present research X-ray diffraction peaks (spectra) is in good agreement with the computational data. The crystalline structure (lattice positions) has been refined by using the "Scherrer method". The X-ray diffraction $\left(\mathrm{Cu}-\right.$ Karadiation, $\lambda=1.54098 \mathrm{~A}^{\circ}$ ) showed the $\mathrm{d}$-spacing value ranging between 1.23617 to 2.79997and the volume of "hexagonal wurtzite unit cell" was 68.55 (units) [32].

\subsubsection{Lattice parameters}

By using the values of miller indices (hkl), the lattice parameters for $\mathrm{ZnO}$ sample was determined by using the following equations [33-35]. 
Mechanistic Study of Antibacterial Properties of Chemically Synthesize Zinc Oxide (ZnO) Nanoparticles

$$
a=\frac{\lambda}{\sqrt{3 \sin \theta}} \cdot \sqrt{h^{2}+h k+k^{2}} ; c=\frac{\lambda}{2 \sin \theta} \cdot l
$$

Where ' $a$ ' and ' $c$ ' are required lattice parameters, $\lambda$ represent the wavelength of $\mathrm{X}$-rays having the value of $1.540598 \mathrm{~A}$, the values of lattice parameters $(\mathrm{a}, \mathrm{c})$ for the present sample as shown in table 3 .

Table 3: Shows the Lattice Parameters for ' $a$ ' and ' $c$ '

\begin{tabular}{|c|c|c|c|c|}
\hline Serial No. & $\mathbf{N a O H}$ & $\begin{array}{c}\text { Electric Oven } \\
\text { Temperature }\left({ }^{\mathbf{0}} \mathbf{C}\right)\end{array}$ & $\begin{array}{c}\text { Lattice Parameter } \\
\text { 'a' }\end{array}$ & $\begin{array}{c}\text { Lattice parameter } \\
\text { 'c' }\end{array}$ \\
\hline Sample $\mathrm{ZnO}$ & $4 \mathrm{~g}$ & 60 & 4.01 & 4.923 \\
\hline
\end{tabular}

\subsubsection{Volume of Unit Cell}

The volume for hexagonal wurtzite unit cell of $\mathrm{ZnO}$ calculated by using the formula [34, 35]

$$
V=\frac{\sqrt{3}}{2} a^{2} c
$$

Where ' $a$ ' and ' $c$ ' are the lattice parameters which are given in table 4.[35]

Table 4: Volume of unit cell of $\mathrm{ZnO}$ nanoparticles

\begin{tabular}{|c|c|c|c|}
\hline Serial No. & $\mathbf{N a O H}$ & $\begin{array}{c}\text { Electric Oven } \\
\text { Temperature }\left({ }^{\boldsymbol{0}} \mathbf{C}\right)\end{array}$ & Volume of unit cell $(\stackrel{\AA}{\mathbf{A}})$ \\
\hline Sample $\mathrm{ZnO}$ & $4 \mathrm{~g}$ & 60 & 68.55 \\
\hline
\end{tabular}

\subsection{Density of Unit Cell}

Ratio of mass of unit cell to volume of unit cell is called density. It is determined by using the formula [34, 35].

$$
\rho_{x}=\frac{Z M}{N_{A} V}
$$

Where $\mathrm{Z}$ is the number of molecules per unit cell, $\mathrm{M}$ is the molar mass of the sample, $\mathrm{N}_{\mathrm{A}}$ is Avogadro's number, $\mathrm{V}$ is the volume of unit cell. The density of unit cell depends on the unit cell volume and molar mass of the sample. Density of unit cell of $\mathrm{ZnO}$ NPs is given in table 5 .

Table 5: Density of unit cell of $\mathrm{ZnO}$ nanoparticles

\begin{tabular}{|c|c|c|c|}
\hline Serial No. & NaOH & $\begin{array}{c}\text { Electric Oven } \\
\text { Temperature }\left({ }^{\mathbf{0}} \mathbf{C}\right)\end{array}$ & Density $\left(\mathbf{g} / \mathbf{c m}^{\mathbf{3}}\right)$ \\
\hline Sample $\mathrm{ZnO}$ & $4 \mathrm{~g}$ & 60 & 7.49 \\
\hline
\end{tabular}

\subsection{Antibacterial activity of $\mathrm{ZnO}$ nanoparticles}

$\mathrm{ZnO}$ NPs are said to be more effective against Gram positive microbes [36] but the effective antibacterial activity against gram negative is observed in this study as it is already described [37]. The choice of $\mathrm{ZnO}$ NPs for antibacterial activity is based upon its safety for use and for their activity any special or additional treatment is not required since these are activated visible light [14] which favors the utility of $\mathrm{ZnO}$ at wide range of goods. ZnO NPs $(0.4 \mathrm{mg} / \mu \mathrm{L}$ and $0.8 \mathrm{mg} / \mu \mathrm{L})$ were tested for antibacterial activity against gram negative a non-pathogenic microbial strain E.coli DH5 $\alpha$ (shown in figure $2 \mathrm{a}$ and $2 \mathrm{~b}$ ). 
Rehman et al., Adv. Nan. Res.; Vol. 2 Issue 1, pp: 42-52, 2019

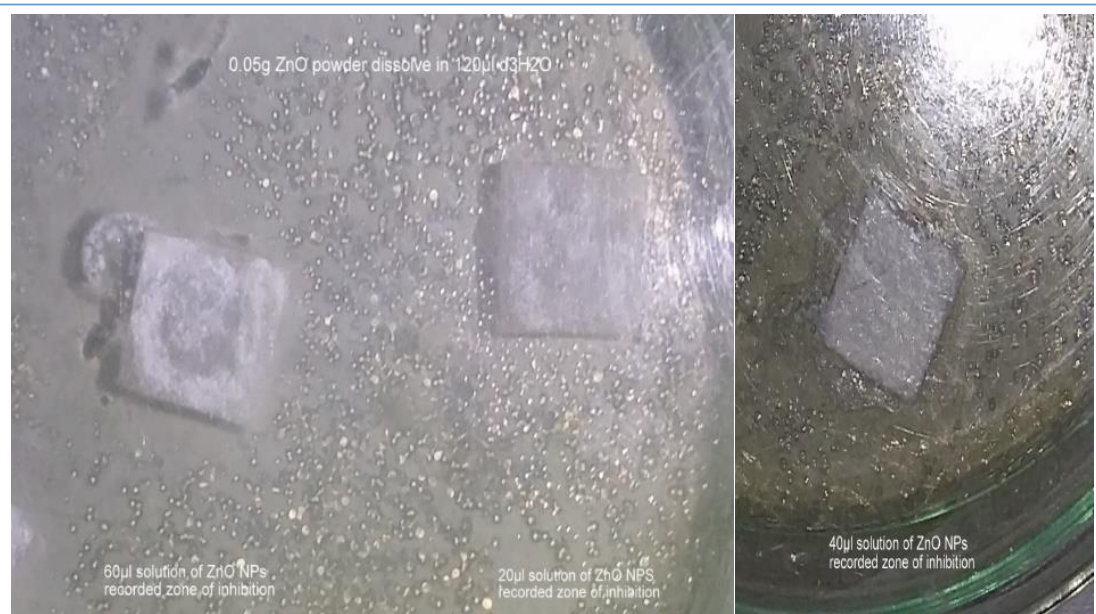

Figure 2a: Zone of inhibition observed by $0.4 \mathrm{mg} / \mu \mathrm{L}$ zinc oxide nanoparticles

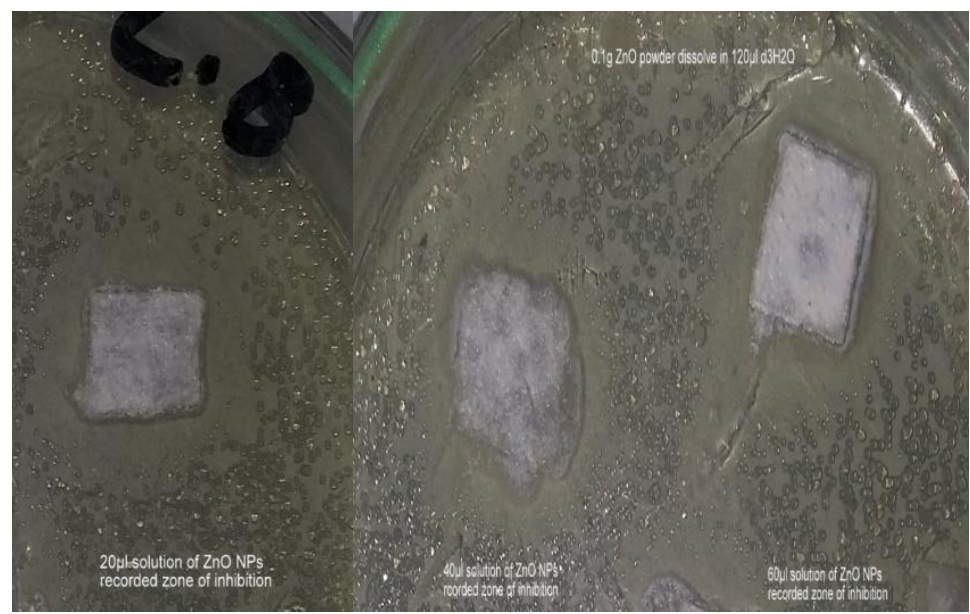

Figure 2b: Zone of inhibition observed by $0.8 \mathrm{mg} / \mu \mathrm{L}$ zinc oxide nanoparticles

The experiments were performed in triplicated to get the accurate observations, the each of triplicated experiment revealed almost similar results for both $0.4 \mathrm{mg} / \mu \mathrm{L}$ and $0.8 \mathrm{mg} / \mu \mathrm{L}$, Set A and Set B respectively. The zone of inhibition was more effective for $0.8 \mathrm{mg} / \mu \mathrm{L}$ than of $0.4 \mathrm{mg} / \mu \mathrm{L}$ which indicated amount of ZnO NPs had direct relationship with antibacterial activity shown in figure-3 (a, b), where it was observed as the amount of $\mathrm{ZnO}$ nanoparticles increases in solution contained by the disc so does the zone of inhibition also increases.

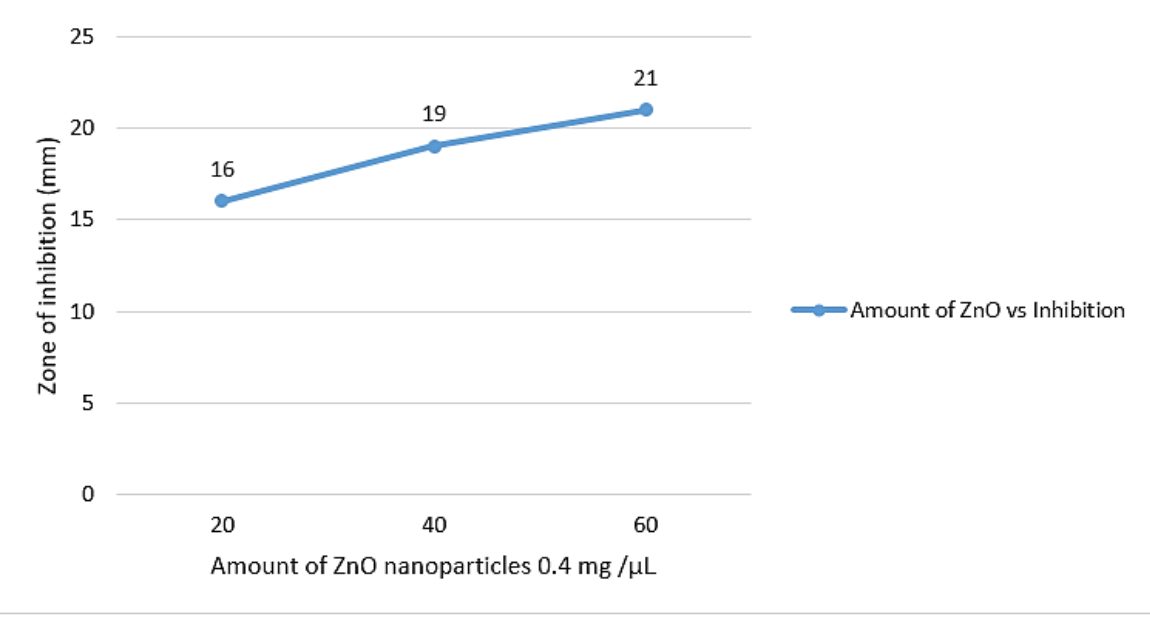

Figure 3a: Effect of $0.4 \mathrm{mg} / \mu \mathrm{L}$ of $\mathrm{ZnO}$ nanoparticles on zone of inhibition. Along $x$-axis, volumetric solution containing amount of nanoparticles. Along y-axis, the zone of inhibition observed in mm. 


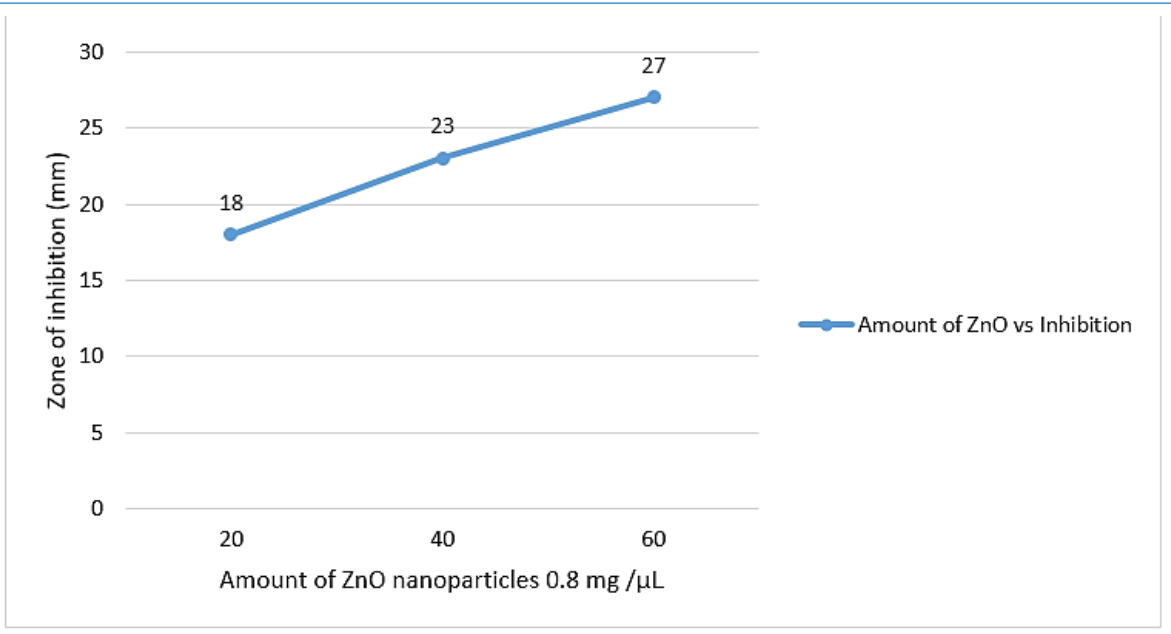

Figure 3b: Effect of $0.8 \mathrm{mg} / \mu \mathrm{L}$ of $\mathrm{ZnO}$ nanoparticles on zone of inhibition. Along $x$-axis, volumetric solution containing amount of nanoparticles. Along y-axis, the zone of inhibition observed in $\mathrm{mm}$.

The proportional effect amount of zinc oxide nanoparticles with inhibition zone seems to make it promising antibacterial agent. The various amount of $\mathrm{ZnO}$ NPs on disc for antibacterial activity was recorded. Table 6 contains zone of inhibition data for each set with its standard deviation.

Table 6: Zone of inhibition recorded using different amount of zinc oxide nanoparticles

\begin{tabular}{|c|c|c|c|}
\hline Bacterial strain & $\begin{array}{c}\text { Amount of ZnO } \\
\text { NPs in solution } \\
(\mathbf{m g} / \boldsymbol{\mu l})\end{array}$ & $\begin{array}{c}\text { Amount of ZnO } \\
\text { NPs in in disc } \\
(\boldsymbol{\mu} \mathbf{L})\end{array}$ & $\begin{array}{c}\text { Zone of inhibition } \\
\text { diameter in mm } \\
\text { Means of triplicate } \pm \\
\text { standard deviation }\end{array}$ \\
\hline \multirow{4}{*}{ E. coli DH5 alpha } & \multirow{3}{*}{0.4} & 20 & $16 \pm 1.5$ \\
\cline { 2 - 4 } & \multirow{2}{*}{0.8} & 40 & $19 \pm 2.0$ \\
\cline { 3 - 4 } & & 60 & $21 \pm 1.7$ \\
\cline { 3 - 4 } & & 20 & $18 \pm 1.7$ \\
\cline { 2 - 4 } & & 40 & $23 \pm 1.7$ \\
\hline
\end{tabular}

\subsection{Mechanism of antibacterial activity}

The most effective and potential antibacterial mechanism for $\mathrm{ZnO}$ is release of reactive oxygen species.

\subsubsection{Reactive Oxygen Species (ROS)}

The $\mathrm{ZnO}$ provides oxygen species from its surface. The reactive oxygen species involve production of superoxide and hydrogen peroxide hydrolyze bacterial cell wall making bacteria off guard, resulting in leakage of cellular contents eventually to death of microbe. The following equations describe the formation of reactive oxygen species [38]. $\mathrm{ZnO}$ oxide has advantage in ease of use due to its activation under visible light by formation of electron-hole pairs $\left(\mathrm{e}^{-} \mathrm{h}^{+}\right)$.

$$
\mathrm{ZnO}+h v \longrightarrow \mathrm{e}^{-}+\mathrm{h}^{+}
$$

The holes split water molecule employing $\mathrm{ZnO}$ suspension and from $\cdot \mathrm{OH}$ and $\mathrm{H}^{+}$.

$$
\mathrm{h}^{+}+\mathrm{H}_{2} \mathrm{O} \longrightarrow \cdot \mathrm{OH}+\mathrm{H}^{+}
$$

Dissolved oxygen reacts with electron resulting in superoxide anion.

$$
\mathrm{e}^{-}+\mathrm{O}_{2} \quad \longrightarrow \quad \mathrm{O}_{2}^{-}
$$

Superoxide anions give rise to $\mathrm{HO}_{2} \cdot$ radicals by reacting to hydrogen ion.

$$
\cdot \mathrm{O}_{2}{ }^{-}+\mathrm{H}^{+} \longrightarrow \mathrm{HO}_{2} \cdot
$$

$\mathrm{HO}_{2} \cdot$ reacts to electrons and hydrogen ion and forms hydrogen peroxide

$$
\mathrm{HO}_{2} \cdot+\mathrm{H}^{+}+\mathrm{e}^{-} \quad \longrightarrow \mathrm{H}_{2} \mathrm{O}_{2}
$$


The negative charged species such as hydroxyl and superoxide anion cannot get into to cell membrane, but hydrogen peroxide has ability to penetrate into cell wall and cell membrane, hence leading to bactericidal affect. In gram negative bacteria, cell wall is composed of lipopolysaccharides which enables bacteria to withstand for harsh conditions and provides resistance against antibiotics. By use of $\mathrm{ZnO}$ NPs employing release of reactive oxygen species (ROS) there are multiple factors which are involved in antibacterial activity. Negatively charged species generated by $\mathrm{ZnO}$ NPs, hydroxyl and superoxide anion act at surface of bacteria like cell wall along with $\mathrm{Zn}$ toxicity providing more potential for being antibacterial activity. Furthermore, hydrogen peroxide dissolve cell membrane as well as effecting cytoplasmic activities [39].

\subsection{Effectiveness of Sol-Gel method for ZnO NPs}

Sol-Gel is simple and inexpensive method for preparation of $\mathrm{ZnO}$ NPs. The fine quality of NPs is obtained by removal of solvent from gelatinized structure. The fine powder of NPs is rich in quality along with effectiveness providing large surface area to NPs for its mechanism of action which enhances the antibacterial properties. Other approaches are also employed for the production and subjected to antibacterial activity. By comparing ZnO NPs prepared by Sol-gel method and ZnO NPs coated on tetron fabric have dramatic difference in antibacterial activity. As in $\mathrm{ZnO}$ NPs coated on the tetron fabric did not have any potential antibacterial activity against $E$. coli, a gram-negative bacteria, which is resistant towards this method [40]. The data generated from this study showed ZnO NPs have very effective antibacterial activity against a gram-negative microbe. The preparation method for $\mathrm{ZnO}$ NPs is required to explore in broad spectrum microbial strains. Since there is antibiotic resistance is emerging for natural compounds posing a serious threat in terms of health and economic issues, there is need of alternative agent which can be used to target the pathogenic strains of bacteria specially Gram negative bacteria which hinders to antibiotic due to their cell wall structure. In light of these events, the chemically synthesized non-toxic $\mathrm{ZnO}$ nanoparticles can be employed as antibiotic drug regarding to its safe use and bactericidal potential.

\section{Conclusion}

Zinc Oxide nanoparticles ( $\mathrm{ZnO} N P s$ ) in powder form were prepared by Sol gel method from a zinc acetate precursor and sodium hydroxide. X-ray diffraction (XRD) patterns of zinc oxide samples were recorded using X-ray powder diffractometer using $\mathrm{Cu}-\mathrm{Ka}$ radiation $(\lambda=1.540598 \mathrm{~A})$ with 2 theta ranging from 20 to $80 \mathrm{~nm}$. The crystalline size of $\mathrm{ZnO}$ sample was calculated using Debye Scherer's formula and Lattice parameters were measured using miller indices. The XRD pattern of $\mathrm{ZnO}$ sample showed close resemblance with the original patterns. The antibacterial activity of $\mathrm{ZnO}$ NPs, prepared by sol-gel method, showed potential results against a gram-negative bacterium, E. coli, by release of reactive oxygen species (ROS). We are able to conclude concerning the achieved results that the zinc oxide nanoparticles possibly will be purposed as effectual and command full products against bacteria in future. Anti-microbial activity is based upon size and type of $\mathrm{ZnO}$ NPs as much the particle size is small and fines as much the surface area is available for its activity against microbes. The antibacterial activity of $\mathrm{ZnO}$ nanoparticles was determined for non-pathogenic Gram-negative microbial strain Escherichia coli. Thedisc diffusion method was employed for the antimicrobial activity of $\mathrm{ZnO} N P s$ at various amounts of $0.4 \mathrm{mg} / \mu \mathrm{L}$ and $0.8 \mathrm{mg} / \mu \mathrm{L}$ and zone of inhibition was measured. It was observed that as the amount of $\mathrm{ZnO} N P$ s increased as did the zone of inhibition which indicated the bactericidal effect. The mechanistic approach for $\mathrm{ZnO} N P$ s is release of reactive oxygen species. ROS are potential bactericidal effect as the results of current research showed that $\mathrm{ZnO}$ nanoparticles have an excellent antimicrobial activity against Escherichia coli.

\section{Declarations}

\section{$5.1 \quad$ Acknowledgement}

We are very thankful to the first author (A.R) supervisor Dr. Ayesha Younus from University of Agriculture Faisalabad and Miss. Sara from CABB for their guidance to conduct this research experiments. 


\subsection{Competing Interests}

All the authors declare no conflict of interest in this research work.

\section{How to Cite this Article:}

A. Rehman et al., "Mechanistic Study of Antibacterial Properties of Chemically Synthesize Zinc Oxide Nanoparticles", Adv. Nan. Res., vol. 2, no. 1, pp. 42-52, Oct. 2019. doi:10.21467/anr.2.1.42-52

\section{References}

[1] A. Singh, N. Singh, I. Hussain, H. Singh, and S. Singh, "Plant-nanoparticle interaction: an approach to improve agricultural practices and plant productivity," Int J Pharm Sci Invent, vol. 4, pp. 25-40, 2015.

[2] P. K. Stoimenov, R. L. Klinger, G. L. Marchin, and K. J. Klabunde, "Metal oxide nanoparticles as bactericidal agents," Langmuir, vol. 18, pp. 6679-6686, 2002.

[3] K. S. Siddiqi, A. ur Rahman, and A. Husen, "Properties of zinc oxide nanoparticles and their activity against microbes," Nanoscale research letters, vol. 13, p. 141, 2018.

[4] B. Ashe, "A Detail investigation to observe the effect of zinc oxide and Silver nanoparticles in biological system," 2011.

[5] K. S. Siddiqi and A. Husen, "Green synthesis, characterization and uses of palladium/platinum nanoparticles," Nanoscale research letters, vol. 11, p. 482, 2016.

[6] A. Thill, O. Zeyons, O. Spalla, F. Chauvat, J. Rose, M. Auffan, et al., "Cytotoxicity of CeO2 nanoparticles for Escherichia coli. Physico-chemical insight of the cytotoxicity mechanism," Environmental science \& technology, vol. 40, pp. 6151-6156, 2006.

[7] L. L. Zhang, B. Chen, L. L. Xie, and Z. F. Li, "Study on the antimicrobial properties of ZnO suspension against Gram-positive and Gram-negative bacteria strains," in Advanced Materials Research, 2012, pp. 1488-1491

[8] I. Sondi and B. Salopek-Sondi, "Silver nanoparticles as antimicrobial agent: a case study on E. coli as a model for Gram-negative bacteria," Journal of colloid and interface science, vol. 275, pp. 177-182, 2004.

[9] H.-L. Liu and T. C.-K. Yang, "Photocatalytic inactivation of Escherichia coli and Lactobacillus helveticus by ZnO and TiO2 activated with ultraviolet light," Process Biochemistry, vol. 39, pp. 475-481, 2003.

[10] P.-J. Lu, S.-C. Huang, Y.-P. Chen, L.-C. Chiueh, and D. Y.-C. Shih, "Analysis of titanium dioxide and zinc oxide nanoparticles in cosmetics," Journal of food and drug analysis, vol. 23, pp. 587-594, 2015.

[11] J. Xie, Y. Cao, D. Jia, Y. Li, and Y. Wang, "Solid-state synthesis of Y-doped ZnO nanoparticles with selective-detection gas-sensing performance," Ceramics International, vol. 42, pp. 90-96, 2016.

[12] H. Chen and R. Yada, "Nanotechnologies in agriculture: new tools for sustainable development," Trends in Food Science \& Technology, vol. 22, pp. 585-594, 2011.

[13] T. H. Grossman, A. L. Starosta, C. Fyfe, W. O'Brien, D. M. Rothstein, A. Mikolajka, et al., "Target-and resistance-based mechanistic studies with TP-434, a novel fluorocycline antibiotic," Antimicrobial agents and chemotherapy, vol. 56, pp. 2559-2564, 2012.

[14] N. Jones, B. Ray, K. T. Ranjit, and A. C. Manna, "Antibacterial activity of ZnO nanoparticle suspensions on a broad spectrum of microorganisms," FEMS microbiology letters, vol. 279, pp. 71-76, 2008.

[15] J. W. Rasmussen, E. Martinez, P. Louka, and D. G. Wingett, "Zinc oxide nanoparticles for selective destruction of tumor cells and potential for drug delivery applications," Expert opinion on drug delivery, vol. 7, pp. 1063-1077, 2010.

[16] P. K. Mishra, H. Mishra, A. Ekielski, S. Talegaonkar, and B. Vaidya, "Zinc oxide nanoparticles: a promising nanomaterial for biomedical applications," Drug discovery today, vol. 22, pp. 1825-1834, 2017.

[17] S. Kim, S. Y. Lee, and H.-J. Cho, "Doxorubicin-wrapped zinc oxide nanoclusters for the therapy of colorectal adenocarcinoma," Nanomaterials, vol. 7, p. 354, 2017.

[18] H. M. Xiong, "ZnO nanoparticles applied to bioimaging and drug delivery," Advanced Materials, vol. 25, pp. 5329-5335, 2013.

[19] Y. Zhang, T. R Nayak, H. Hong, and W. Cai, "Biomedical applications of zinc oxide nanomaterials," Current molecular medicine, vol. 13, pp. 1633-1645, 2013.

[20] K.-N. Yu, T.-J. Yoon, A. Minai-Tehrani, J.-E. Kim, S. J. Park, M. S. Jeong, et al., "Zinc oxide nanoparticle induced autophagic cell death and mitochondrial damage via reactive oxygen species generation," Toxicology in Vitro, vol. 27, pp. 1187-1195, 2013.

[21] K. R. Raghupathi, R. T. Koodali, and A. C. Manna, "Size-dependent bacterial growth inhibition and mechanism of antibacterial activity of zinc oxide nanoparticles," Langmuir, vol. 27, pp. 4020-4028, 2011.

[22] G. Tortora, B. Funke, and C. Case, "Microbiology: An Introduction. Global Edition," ed: USA: Pearson Education, 2015.

[23] L. Boyanova, "Direct Gram staining and its various benefits in the diagnosis of bacterial infections," Postgraduate medicine, vol. 130, pp. 105-110, 2018..

[24] A. Merah, A. Abidi, H. Merad, N. Gherraf, M. Iezid, and A. Djahoudi, "Comparative Study of the Bacteriological Activity of Zinc Oxide and Copper Oxide Nanoparticles," Acta Scientifica Naturalis, vol. 6, pp. 63-72, 2019.

[25] S. Dwivedi, R. Wahab, F. Khan, Y. K. Mishra, J. Musarrat, and A. A. Al-Khedhairy, "Reactive oxygen species mediated bacterial biofilm inhibition via zinc oxide nanoparticles and their statistical determination," PloS one, vol. 9, p. e111289, 2014.

[26] A. B. Sangannavar, B. Sumangala, and N. Shetty, "Phenotypic detection of ESBL among E. coli and Klebiella pneumoniae by modified CLSI guidelines," International Journal of Medical Microbiology and Tropical Diseases, vol. 4, pp. 117-121, 2018.

[27] H. Meruvu, M. Vangalapati, S. C. Chippada, and S. R. Bammidi, "Synthesis and characterization of zinc oxide nanoparticles and its antimicrobial activity against Bacillus subtilis and Escherichia coli," J. Rasayan Chem, vol. 4, pp. 217-222, 2011. 
[28] J. Jiang, J. Pi, and J. Cai, "The advancing of zinc oxide nanoparticles for biomedical applications," Bioinorganic chemistry and applications, vol. 2018, 2018.

[29] S. Lele and T. Anantharaman, "Influence of crystallite shape on particle size broadening of Debye-Scherrer reflections," in Proceedings of the Indian Academy of Sciences-Section A, 1966, pp. 261-274.

[30] U. Holzwarth and N. Gibson, "The Scherrer equation versus the'Debye-Scherrer equation'," Nature nanotechnology, vol. 6, p. 534, 2011.

[31] J. Lee, A. Easteal, U. Pal, and D. Bhattacharyya, "Evolution of ZnO nanostructures in sol-gel synthesis," Current Applied Physics, vol. 9, pp. 792-796, 2009.

[32] S. S. Kumar, P. Venkateswarlu, V. R. Rao, and G. N. Rao, "Synthesis, characterization and optical properties of zinc oxide nanoparticles," International Nano Letters, vol. 3, p. 30, 2013.

[33] E. H. Kisi and M. M. Elcombe, "u parameters for the wurtzite structure of ZnS and ZnO using powder neutron diffraction," Acta Crystallographica Section C: Crystal Structure Communications, vol. 45, pp. 1867-1870, 1989.

[34] B. Cullity, "Elements of X-ray diffraction: a practical approach," ed: Addison-Wesley Publishing Company Inc., California, 1956.

[35] V. Mote, J. Dargad, and B. Dole, "Effect of Mn doping concentration on structural, morphological and optical studies of ZnO nanoparticles," Nanoscience and Nanoengineering, vol. 1, pp. 116-122, 2013.

[36] Z. Huang, X. Zheng, D. Yan, G. Yin, X. Liao, Y. Kang, et al., "Toxicological effect of ZnO nanoparticles based on bacteria," Langmuir, vol. 24, pp. 4140-4144, 2008.

[37] G. R. Navale, M. Thripuranthaka, D. J. Late, and S. S. Shinde, "Antimicrobial activity of ZnO nanoparticles against pathogenic bacteria and fungi," JSM Nanotechnol Nanomed, vol. 3, p. 1033, 2015.

[38] R. Vijayaraghavan, "Zinc oxide based inorganic antimicrobial agents," International Journal of Science Research, vol. 1, pp. 35-46, 2012.

[39] E. A. S. Dimapilis, C.-S. Hsu, R. M. O. Mendoza, and M.-C. Lu, "Zinc oxide nanoparticles for water disinfection," Sustainable Environment Research, vol. 28, pp. 47-56, 2018.

[40] E. Z. Karimi and M. Ansari, "Comparison of Antibacterial Activity of ZnO Nanoparticles Fabricated by Two Different Methods and Coated on Tetron Fabric," The Open Biotechnology Journal, vol. 12, 2018.

\section{Publish your research article in AIJR journals-} Online Submission and Tracking

$\checkmark$ Peer-Reviewed

$\checkmark$ Rapid decision

$\checkmark \quad$ Immediate Publication after acceptance

$\checkmark \quad$ Articles freely available online

$\checkmark \quad$ Retain full copyright of your article.

Submit your article at journals.aijr.in
Publish your books with AIJR publisher-

$\checkmark$ Publish with ISBN and DOI.

$\checkmark$ Publish Thesis/Dissertation as Monograph.

$\checkmark$ Publish Book Monograph.

$\checkmark$ Publish Edited Volume/ Book.

$\checkmark$ Publish Conference Proceedings

$\checkmark$ Retain full copyright of your books.

Submit your manuscript at books.aijr.org 